\title{
Natural Agglutinins of Normal Rat Sera against Erythrocytes of Human Blood Groups
}

\author{
(A preliminary report)
}

\author{
Takao Matsumoto \\ Zoological Institute, Hokkaido University
}

Received September 14, 1960.

The roles of natural antibodies in the success of heterografting have long been discussed by many investigators. Most authors have suggested that the conditioning of the host with cortisone or X-rays might cause a reduction of natural antibodies, resulting possibly in the abrogation of acquired immunity to lead to the success of heterografting. Some workers have pointed out the fact that several strains of rats possess antibodies against human erythrocytes of blood groups $\mathrm{A}$ and $\mathrm{AB}$ (Aptekman \& Bogden 1956, Pikovski \& Schlesinger 1959).

Since the success of heterografting of human tumors into animals seems to be affected by antigenic relations between hosts and grafts, it is of importance to know the presence and function of natural antibodies in animals. With that idea in mind, the present study was undertaken on the occurrence and fate of natural antibodies in normal and pretreated rats from several strains.

The author wishes to offer his sincere thanks to Professor Sajiro Makino who showed keen interest in this subject and read through the manuscript. Further, the author is deeply grateful to other members of this laboratory for kindly supplying rats for this study.

\section{Material and methods}

Test sera: Test blood was obtained by cardiac puncture from normal mature rats of several strains such as Wistar (W/Ma), Gifu, Osborn-Mendel, Long-Evans, Buffalo, and WB ( $\mathrm{F}_{1}$ from Wistar $\times$ Buffalo), weighing about 200 to 300 grams and also from some rats which had received pretreatment with cortisone or X-rays. Sera were separated from the blood samples by placing them in a refrigerator at $5^{\circ} \mathrm{C}$ overnight. The sera thus prepared were reacted to test antigen-cells by agglutinin-reaction as described in the former report (Matsumoto 1958).

Antigens: Human erythrocytes of blood groups A, B and AB from both sexes

Contribution No. 480 from the Zoological Institute, Faculty of Science, Hokkaido University, Sapporo, Japan.

Supported by a grant from the Damon Runyon Memorial Fund for Cancer Research to S. Makino (DRG-563). 
used for test antigen-cells. The blood for each group was suspended in an anticoagulant cosisting of $78 \mathrm{mg}$ of acidic citrate, $360 \mathrm{mg}$ of sodium citrate and $360 \mathrm{mg}$ of glucose per $\mathrm{ml}$. After the blood had been repeatedly washed with saline, the erythrocytes were collected by centrifugation for 5 minutes at $3,000 \mathrm{rpm}$, and three per cent erythrocyte suspension in 0.9 per cent saline was prepared to use as testing agglutinin titers. Hemolysed cells were discarded. Two drops of each erythrocyte suspension (about $0.04 \mathrm{ml}$ ) were mixed in each tube of diluted serum in the manner as previously reported (Matsumoto 1958). Readings of titers were made after placing the tubes in an incubator for 2 hours at $37^{\circ} \mathrm{C}$. The agglutinin titers were determined after further placing them at room temparature overnight.

\section{Results}

1. Natural agglutinins of normal rat sera: Attempt was made at first to determine the agglutinin titers of normal sera obtained from several rat strains against erythrocytes of human blood grolips, A, B and AB. The results derived are shown in Table 1. Rats of most strains here examined showed agglutinin-reaction at various degreees against the human erythrocytes. Generally the reactions of sera were rather more intense to the erythrocytes of blood groups $A$ and $A B$ than to those of blood group $B$. Among the rat strains tested, male WB rats showed the highest agglutinin-reaction against blood cells of all groups. Female Long-Evans rats showed mostly negligible reaction in all experimental conditions. It is interesting to note that agglutinin titers are higher in WB rats than in those of parent strains. In most cases, male rats showed a different reaction-pattern from females: the agglutinin titers of males were generally higher than those of females, except Gifu rats whose titers were high in females.

Table 1. Natural agglutinin titers of normal rat sera from several strains against the erythrocytes of human blood groups $\mathrm{A}, \mathrm{B}$ and $\mathrm{AB}$.

\begin{tabular}{|c|c|c|c|c|}
\hline & & \multicolumn{3}{|c|}{$\begin{array}{l}\text { Agglutinin titers to the erythrocytes of } \\
\text { human blood groups: }\end{array}$} \\
\hline & & $\mathrm{A}$ & B & $\mathrm{AB}$ \\
\hline Male & $\begin{array}{l}\text { Wistar rat } \\
\text { Osborn-Mendel rat } \\
\text { Long-Evans rat } \\
\text { Gifu rat } \\
\text { Buffalo rat } \\
\text { WB rat }\end{array}$ & $\begin{array}{ll}1 & : 4 \\
1 & : 16 \\
1 & : 64 \\
1 & : 8 \\
1 & : 16 \\
1 & : 128\end{array}$ & 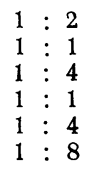 & $\begin{array}{ll}1 & : 4 \\
1 & : 16 \\
1 & : 32 \\
1 & : 2 \\
1 & : 32 \\
1 & : 32\end{array}$ \\
\hline Female & $\begin{array}{l}\text { Wistar rat } \\
\text { Osborn-Mendel rat } \\
\text { Long-Evans rat } \\
\text { Gifu rat } \\
\text { Buffalo rat } \\
\text { WB rat }\end{array}$ & $\begin{array}{ll}1 & : 2 \\
1 & : 2 \\
1 & : 2 \\
1 & : 32 \\
1 & : 8 \\
1 & : 2\end{array}$ & 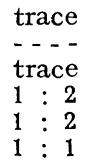 & $\begin{array}{ll}1 & : 2 \\
1 & : 4 \\
1 & : 1 \\
1 & : 16 \\
1 & : 3 \\
1 & : 4\end{array}$ \\
\hline
\end{tabular}

In the light of the above findings, it is evident that natural antibodies of normal healthy rat differ by rat strains, and that natural antibodies are generally lower in females than in males.

2. Changes of natural agglutinin as in pretreated rats: The change of natural 
agglutinin titers of rat sera was studied following a single intraperitoneal injection of cortisone. Ten normal male rats from both Wistar and Long-Evans strains each were injected intraperitoneally with $120 \mathrm{mg}$ of cortisone acetate per $\mathrm{kg}$ body weight, and the sera were collected 2 days after the injection. The control sera for comparison were obtained from the rats used for cortisone-treatment before the injection. As shown in Table 2, male Wistar rats whose agglutinin titers were comparatively low even in untreated condition showed little reaction against all antigen-cells after the cortisone-treatment. Male Long-Evans rats also showed marked fall of agglutinin titers against the erythrocytes of blood groups, $\mathrm{A}$ and $\mathrm{AB}$. The above results indicate that cortisone may suppress the function of natural antibodies against heterologous antigens.

Table 2. Agglutinin titers of rat sera preared before or after cortisonetreatment. The titers are expressed as maximum dilution of sera at which agglutinin-reaction occurred.

\begin{tabular}{|c|c|c|c|c|}
\hline & & \multicolumn{3}{|c|}{ Antigen cell } \\
\hline & & A & B & A B \\
\hline \multirow{2}{*}{$\begin{array}{l}\text { Male Wistar } \\
\text { rat serum }\end{array}$} & $\begin{array}{l}\text { Before } \\
\text { treatment }\end{array}$ & $1: 4$ & $1: 2$ & $1: 4$ \\
\hline & $\begin{array}{l}\text { After } \\
\quad \text { treatment }\end{array}$ & $1: 1$ & trace & $1: 1$ \\
\hline \multirow{2}{*}{$\begin{array}{l}\text { Male Long- } \\
\text { Evans rat } \\
\text { serum }\end{array}$} & $\begin{array}{l}\text { Before } \\
\text { treatment }\end{array}$ & $1: 64$ & $1: 4$ & $1: 32$ \\
\hline & $\begin{array}{l}\text { After } \\
\quad \text { treatment }\end{array}$ & $1: 2$ & $\begin{array}{l}\text { not } \\
\text { tested }\end{array}$ & $1: 2$ \\
\hline
\end{tabular}

The results of the above experiment were re-examined after pretreatment with $\mathrm{X}$-rays. Before the exposure to X-rays, normal sera samples were collected from healthy male rats from both Wistar and WB strains weighing about 100 grams each, and tested to determine the natural agglutinin titers for comparison. As summarized in Table 3, these sera showed a considerably high agglutinin-reaction to the test antigencells. Ten days later, the same rats were exposed to X-rays at $150 \mathrm{r}$ per kg weight. Two days later, test sera were obtained from those rats, and examined for reaction to the test antigen-cells. The results showed that the sera from $\mathrm{X}$-irradiated rats exhibited a marked decrease in agglutinin titers (Table 3). Male Wistar rats showed no agglutinin-reaction. Male WB rats were also lower in agglutinin titers than that of control ones. From the above results it seems probable that X-rays strongly act to inhibit the function of natural antibodies against the antigen-cells. Seven days after the X-irradiation, however, the antibodies of circulating blood appeared again, showing considerably high agglutinin titers with a value of $1: 32$ in male WB rats and of $1: 4$ in male Wistar rats.

On the basis of the above findings it is apparent that both cortisone and X-rays restrain the production of antibodies for a certain period of time, and that the X-rays 
Table 3. Agglutinin titers of rat sera prepared 2 days after the exposure to X-rays at $150 \mathrm{r}$.

\begin{tabular}{|c|c|c|c|c|}
\hline & & \multicolumn{3}{|c|}{ Antigen cell } \\
\hline & & A & $\mathrm{B}$ & $\mathrm{AB}$ \\
\hline \multirow{2}{*}{$\begin{array}{l}\text { Male Wistar } \\
\text { rat serum }\end{array}$} & $\begin{array}{l}\text { Before } \\
\text { treatment }\end{array}$ & $1: 8$ & $1: 2$ & $1: 4$ \\
\hline & $\begin{array}{l}\text { After } \\
\text { treatment }\end{array}$ & - & - & - \\
\hline \multirow{2}{*}{$\begin{array}{l}\text { Male WB } \\
\text { rat serum }\end{array}$} & $\begin{array}{l}\text { Before } \\
\text { treatment }\end{array}$ & $1: 64$ & $1: 8$ & $1: 32$ \\
\hline & $\begin{array}{l}\text { After } \\
\quad \text { treatment }\end{array}$ & $1: 2$ & - & $1: 2$ \\
\hline
\end{tabular}

exert much stronger influence to inhibit the antibody formation than cortisone does.

3. Effect of cortisone upon the rate of appearance of antibodies: In this experiment, 16 male WB rats in two groups received intraperitoneal inoculation each with $0.5 \mathrm{ml}$ of 3 per cent erythrocyte suspension of human blood group $\mathrm{A}$ as antigen. One day

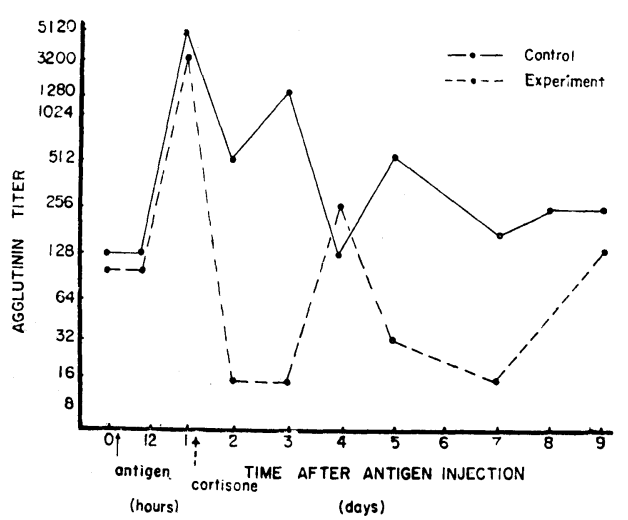

Fig. 1. Mean agglutinin titers from 2 groups of control and of cortisone-treated rats, following an intraperitoneal injection of human erythrocytes of blood group A. Note rapid decline in agglutinin production, a single 120 $\mathrm{mg} / \mathrm{kg}$ cortisone injection 1 day after antigen injection, in contrast to the control group. after the inoculation, cortisone acetate at $120 \mathrm{mg}$ per $\mathrm{kg}$ body weight was injected intraperitoneally into the rats of one group, while those of the other group were untreated for the control of the experiment. The results here obtained are graphed in Figure 1. The induction period was about 12 hours after antigen injection in both control and experimental groups. The maximum peak titers were attained on the first day after antigen injection at a value about $1: 3600$ in the experimental group and 1:5120 in the control one. A gradual decrease of agglutinin titer was observed in control rats 2 days after antigen injection, while the titer value was reduced to 1 : 16 in experimental rats on the first day after cortisone injection. As seen in Figure 1, on the second day, control rats showed a gradual increase of agglutinin titers followed by a subsequent decrease. After the above mode of action was repeated for a few days, a constant titer value was attained in control rats, with high agglutinin titers. In the experimental group, the cortisone-treated rats showed lower agglutinin titers for a few days than untreated ones, and then an increase on the 4 th day of cortisone treatment. During the period from the 5th to 8th day after the cortisone-treatment, the 
reduction of agglutinins was continued until it returned to the normal level on the 9th day. From the above results, it is evident that cortisone may act to suppress the function of antibodies.

\section{Discussion}

The results obtained in the present study indicate that rats of several strains here examined possess natural antibodies to a greater or less degree against the erythrocytes of human blood groups. It is of much interest to know that most sera react rather sensitively to the cells of blood groups $A$ and $A B$, but weakly to those of group B. This implies that rats of several strains possess natural antibodies which react strongly to human erythrocytes of blood groups A and AB. Previously, Aptekman and Bogden (1956) found that antibodies against human erythrocytes of blood groups $\mathrm{A}$ and $\mathrm{AB}$ were present in rats of P.A. strain. Pikovski and Schlesinger (1959) also confirmed the presence of antibodies to A and AB cells of human blood groups. Since the antigenicity of human tumors is regarded as characteristic to the blood groups, the above findings may be important in the consideration of success in heterografting of human tumors into rats.

Further, it is of importance that most male rats from several strains showed higher agglutinin-reaction against all antigen-cells here tested than in female rats. This means either that female rats have generally a wide range of adaptable antigenicity, or that they have a different immunity from that of males.

It has long been considered by many investigators that the immune mechanism of rats is modified by the pre- or post-treatment of the animals with cortisone or X-rays (Taliaferro and Taliaferro 1954, Toolan 1955, 1957, Pikovski et al. 1957, Makinodan and Gengozian 1958, and some others). Makinodan and Gengozian (1958) expressed the view that no quantitative relation between radiation dose and antibody response was apparent in adult mice when mean titer of agglutinins was used as an index of antibody response by the use of sheep red blood cells. The data obtained in this study show that a single $150 \mathrm{r}$ of total body irradiation with $\mathrm{X}$-rays is sufficient to suppress the function of natural antibodies of the rats for about 5 to 7 days. A similar situation was found to occur in the cortisone experiment; a $120 \mathrm{mg}$ dose of cortisone per $\mathrm{kg}$ body weight can inhibit the function of natural antibodies in circulating blood of rats, though the suppression seems to be weaker than that of $\mathrm{X}$ rays. A much higher dosage of cortisone does not always increase the suppression of antibody formation. Taliaferro (1957) stated that maximum antibody suppression occurred when 3 doses of cortisone ( $4 \mathrm{mg} / 100 \mathrm{gm}$ rat/day) were given begining 2 days before and ending on the day of antigen injection, and further that cortisone in similar amounts given after the injection was ineffective. Toolan (1955) suggested that the conditioning of hosts with cortisone caused a reduction of natural antibodies and possibly also a subsequent abrogation of acquired immunity. It has been shown in the present study that cortisone can markedly suppress the antibody formation even after the injection of antigen, but after a certain time, the production of antibody 
begins to recover. This seems to imply that cortisone or X-rays can restrain the activity of antibodies present in the circulaitng blood, but not destroy the function of antibody-forming tissues. The function of natural antibodies in relation to heterografting has been a subject of interest to the author.

\section{Summary}

In an attempt to obtain some information regarding heterografting of human cancer into rats, the presence and function of natural antibodies against the erythrocytes of human blood groups were studied in normal and pretreated rats from several strains. It was shown that the concentration of natural antibodies differ by rat strains, and that the natural antibody titers were comparatively lower in females than in males.

Both cortisone and X-rays act to suppress the production of natural antibodies for a certain period. The antibody formation is more storngly inhibited by X-rays than by cortisone. Cortisone acts to suppress the function of antibodies in circulating blood.

\section{References}

Aptekman, P.M. and Bogden, A.E. 1956. Characterization of the natural hemagglutinins in normal rat serum associated with a negative phase following tumor implantation. Cancer Res. $16: 216-221$.

Makinodan, T. and Gengozian, N. 1958. Primary antibody response to a distantly related heterologous antigen during maximum depression period after varying doses of $\mathrm{X}$ radiation. J. Immunol. $81: 150-154$.

Matsumoto, T. 1958. Differential reactions of homologous antiserum to tumor cells of different rat sacites tumors. Jour. Fac. Sci. Hokkaido Univ. Ser. VI 24 : 31-38.

Pikovski, M. and Schlesinger, M. 1959. Natural agglutinins in rat sera against cells of mouse tumors differing in their transplantability to pretreated rats. Cancer Res. 19: 227232.

Pikovski, M., Tal, C., Schlesinger, M. and Margoliash, E. 1957. Serological changes concomitant with the growth of moues tumors in pretreated rats. Nature $180: 185-186$.

Talifaferro, W.H. 1957. Modification of the immune response by radiation and cortisone. Ann. New York Acad. Sci. 69 : 45-764.

Taliaferro, W.H. and Taliaferro, L.G. 1954. Effect of $\mathrm{X}$ rays on hemolysin formation following various immunization and irradiation procedures. J. Infectious Disease 95 : 117-133.

Toolan, H.W. 1955. The possible role of cortisone in overcoming resistance to the growth of human tissues in heterologous hosts. Ann. New York Acad. Sci. 59 : 394-399.

Toolan, H.W. 1957. Growth of transplantable human tumors in conditioned mice. Transpl. Bull. 4 : 160 . 